\title{
Sulfurovum lithotrophicum gen. nov., sp. nov., a novel sulfur-oxidizing chemolithoautotroph within the $\varepsilon$-Proteobacteria isolated from Okinawa Trough hydrothermal sediments
}

\author{
Correspondence \\ Fumio Inagaki \\ inagaki@jamstec.go.jp
}

\author{
Fumio Inagaki, ${ }^{1}$ Ken Takai, ${ }^{1}$ Kenneth H. Nealson ${ }^{1,2}$ and Koki Horikoshi ${ }^{1}$ \\ ${ }^{1}$ Subground Animalcule Retrieval (SUGAR) Project, Frontier Research System for \\ Extremophiles, Japan Marine Science \& Technology Center (JAMSTEC), 2-15 \\ Natsushima-cho, Yokosuka 237-0061, Japan \\ ${ }^{2}$ Department of Earth Sciences, University of Southern California, 3651 Trousdale Pkwy, \\ Los Angeles, CA 90089-0740, USA
}

\begin{abstract}
A novel mesophilic sulfur- and thiosulfate-oxidizing bacterium, strain $42 \mathrm{BKT}^{\top}$, was isolated from the gas-bubbling sediment at the Iheya North hydrothermal system in the mid-Okinawa Trough, Japan. The isolate was a Gram-negative, non-motile and coccoid to oval-shaped bacterium. Growth was observed at $10-40{ }^{\circ} \mathrm{C}$ (optimum $28-30{ }^{\circ} \mathrm{C}$ ) and in the $\mathrm{pH}$ range $5 \cdot 0-9 \cdot 0$ (optimum 6.5-7·0). Strain $42 \mathrm{BKT}^{\top}$ grew chemolithoautotrophically with elemental sulfur or thiosulfate as a sole electron donor and oxygen (optimum $5 \%$ in gas phase) or nitrate as an electron acceptor. The $\mathrm{G}+\mathrm{C}$ content of the genomic DNA was $48 \cdot 0 \mathrm{~mol} \%$. Phylogenetic analysis based on the 16S rRNA gene sequence indicated that the isolate belonged to the previously uncultivated Group $\mathrm{F}$ within the $\varepsilon$-Proteobacteria, which includes phylotypes of vent epibiont and environmental sequences from global deep-sea cold seep and hydrothermal vent fields. On the basis of the physiological and molecular characteristics of this isolate, the type species of a novel genus, Sulfurovum lithotrophicum gen. nov., sp. nov., is proposed. The type strain is $42 B K T^{\top}$ $\left(=\right.$ ATCC BAA $-797^{\top}=$ JCM $\left.12117^{\top}\right)$.
\end{abstract}

Culture-independent molecular ecological surveys using PCR-amplified 16S rRNA genes have demonstrated over the past decade that the 16S rRNA gene sequences belonging to the $\varepsilon$-Proteobacteria are predominantly recovered from global deep-sea hydrothermal systems (Moyer et al., 1995; Polz \& Cavanaugh, 1995; Reysenbach et al., 2000; Longnecker \& Reysenbach, 2001; Campbell et al., 2001). Predominant prokaryotes in hydrothermal vent environments have been considered as one of the members within the $\varepsilon$-Proteobacteria; however, their physiological properties and ecological significance have long remained undefined because of their resistance to cultivation.

On the basis of $16 \mathrm{~S}$ rRNA gene sequences of strains recovered from the Mid-Atlantic Ridge hydrothermal vent, the diverse uncultivated $\varepsilon$-proteobacterial assemblages were

Published online ahead of print on 20 February 2004 as DOI 10.1099/ ijs.0.03042-0.

The GenBank/EMBL/DDBJ accession number for the 16S rRNA gene sequence of strain $42 B K T^{\top}$ is $A B 091292$.

Graphs showing the effects of temperature, $\mathrm{pH}$ and sea salts and $\mathrm{O}_{2}$ concentration on growth of Sulfurovum lithotrophicum are available as supplementary material in IJSEM Online. classified into six groups (groups A to F; Corre et al., 2001). Two genera within the $\varepsilon$-Proteobacteria, Caminibacter and Nautilia, have been isolated from the tube-dwelling polychaete Alvinella pompejana on the East Pacific Rise hydrothermal system (Alain et al., 2002; Miroshnichenko et al., 2002). Based on $16 \mathrm{~S}$ rRNA gene sequences, these isolates were located within $\varepsilon$-proteobacterial group D. Hydrogenimonas thermophilus within the $\varepsilon$-proteobacterial group $\mathrm{A}$ was isolated from the Indian Ridge hydrothermal vent (Takai et al., 2004). These isolates were strictly anaerobic, moderately thermophilic hydrogen-oxidizers using elemental sulfur as a primary electron acceptor (Table 1). Recently, we reported that a variety of $\varepsilon$-proteobacteria have been successfully isolated from the mid-Okinawa Trough and the Central Indian Ridge hydrothermal vent systems (Takai et al., 2003). The most frequently isolated phylotypes were affiliated to the $\varepsilon$-proteobacterial group B, in line with the results of a culture-independent molecular ecological survey at the Mid-Atlantic Ridge hydrothermal vent (Corre et al., 2001). Sulfurimonas autotrophica, representing the most abundantly cultivated $\varepsilon$-proteobacterial group from the Okinawa hydrothermal vent systems, was recently characterized as a mesophilic, obligatory aerobic sulfur- and thiosulfate-oxidizing bacterium (Inagaki et al., 2003). Here 
Table 1. Characteristics of Sulfurovum lithotrophicum gen. nov., sp. nov. $42 \mathrm{BKT}^{\top}$ and members of the $\varepsilon$-Proteobacteria isolated from deep-sea hydrothermal vent environments

Species: 1, Caminibacter hydrogeniphilus AM1116 ${ }^{\mathrm{T}}$ (data from Alain et al., 2002); 2, Nautilia lithotrophica 525 (Miroshnichenko et al., 2002); 3, Hydrogenimonas thermophilus EP1-55-1\% ${ }^{\mathrm{T}}$ (Takai et al., 2004); 4, Sulfurimonas autotrophica OK10 ${ }^{\mathrm{T}}$ (Inagaki et al., 2003); 5, Sulfurovum lithotrophicum gen. nov., sp. nov. $42 \mathrm{BKT}^{\mathrm{T}}$.

\begin{tabular}{|c|c|c|c|c|c|}
\hline Character & 1 & 2 & 3 & 4 & 5 \\
\hline Temperature for growth $\left({ }^{\circ} \mathrm{C}\right)$ : & Thermophilic & Thermophilic & Thermophilic & Mesophilic & Mesophilic \\
\hline Range & $50-70$ & $37-68$ & $35-65$ & $10-40$ & $10-40$ \\
\hline Optimum & 60 & 53 & 55 & $23-26$ & $28-30$ \\
\hline Morphology & Rod & Rod & Rod & Rod & Coccoid to oval \\
\hline Mobility & + & + & + & + & - \\
\hline $\mathrm{G}+\mathrm{C}$ content $(\mathrm{mol} \%)$ & 29 & 35 & 34 & 35 & 48 \\
\hline Electron donors & $\mathrm{H}_{2}$, organic substrates & $\mathrm{H}_{2}$, formate & $\mathrm{H}_{2}$ & $\mathrm{~S}^{0}, \mathrm{~S}_{2} \mathrm{O}_{3}^{-}$ & $\mathrm{S}^{0}, \mathrm{~S}_{2} \mathrm{O}_{3}^{-}$ \\
\hline Electron acceptors & $\mathrm{S}^{0}, \mathrm{NO}_{3}^{-}$ & $S^{0}$ & $\mathrm{O}_{2}, \mathrm{~S}^{0}, \mathrm{NO}_{3}^{-}$ & $\mathrm{O}_{2}$ & $\mathrm{O}_{2}, \mathrm{NO}_{3}^{-}$ \\
\hline Phylogenetic position & Group D & Group D & Group A & Group B & Group F \\
\hline
\end{tabular}

we report the characterization of a novel mesophilic strain representative of $\varepsilon$-proteobacterial group $\mathrm{F}$ from deep-sea hydrothermal sediment at the Iheya North site in the midOkinawa Trough back-arc hydrothermal system.

\section{Sample collection}

Sediment samples were collected from the gas-bubbling site in the Iheya North hydrothermal field, mid-Okinawa Trough, Japan $\left(27^{\circ} 47 \cdot 38^{\prime} \mathrm{N} 126^{\circ} 53 \cdot 87^{\prime} \mathrm{E}\right)$, at a depth of $1033 \mathrm{~m}$ using the push-core sampler by means of the manned submersible Shinkai 2000 during NT02-06 scientific cruise aboard the R/V Natsushima performed in April 2002. The sampling site was located approximately $100 \mathrm{~m}$ east from an active hydrothermal vent site. The recovered length of core was $5 \mathrm{~cm}$ and the sediment was composed of grey angular coarse sand with white coarse sand at the surface. For the slurry sample, the sediment was placed immediately into a $100 \mathrm{ml}$ sterilized glass bottle (Schott Glaswerke) with $50 \mathrm{ml}$ sterilized MJ synthetic sea water containing $0.05 \%(\mathrm{w} / \mathrm{v})$ sodium sulfide and then tightly sealed with a butyl rubber cap under a gas phase of $100 \% \mathrm{~N}_{2}$ $(150 \mathrm{kPa})$ and stored at $4{ }^{\circ} \mathrm{C}$ onboard (Takai et al., 2003). The MJ synthetic sea water was composed $\left(1^{-1}\right)$ of $30 \cdot 0 \mathrm{~g}$ $\mathrm{NaCl}, 0 \cdot 14 \mathrm{~g} \mathrm{CaCl}_{2} .2 \mathrm{H}_{2} \mathrm{O}, 3 \cdot 40 \mathrm{~g} \mathrm{MgSO}_{4}, 4 \cdot 18 \mathrm{~g} \mathrm{MgCl}_{2}$, $0.14 \mathrm{~g} \quad \mathrm{~K}_{2} \mathrm{HPO}_{4}, 0.33 \mathrm{~g} \mathrm{KCl}, 0.25 \mathrm{~g} \mathrm{NH} \mathrm{NH}_{4} \mathrm{Cl}, 0.5 \mathrm{mg}$ $\mathrm{NiCl}_{2} \cdot 6 \mathrm{H}_{2} \mathrm{O}, 0.5 \mathrm{mg} \mathrm{Na} \mathrm{SeO}_{3} .5 \mathrm{H}_{2} \mathrm{O}, 0.01 \mathrm{~g} \mathrm{FeCl}_{2}$ and $10 \mathrm{ml}$ trace mineral solution (Balch et al., 1979).

\section{Enrichment and purification}

A portion of $500 \mu \mathrm{l}$ slurry was inoculated into $5 \mathrm{ml} \mathrm{MJ}$ basal medium without sodium sulfide, made up in $\mathrm{MJ}$ synthetic water: $0.15 \%(\mathrm{w} / \mathrm{v}) \mathrm{NaHCO}_{3}, 0.15 \%(\mathrm{w} / \mathrm{v})$ $\mathrm{Na}_{2} \mathrm{~S}_{2} \mathrm{O}_{3} .5 \mathrm{H}_{2} \mathrm{O}$ and $0.01 \%(\mathrm{v} / \mathrm{v})$ vitamin mixture (Balch et al., 1979). Gas mixtures of $\mathrm{N}_{2} / \mathrm{CO}_{2} / \mathrm{O}_{2} \quad(77: 17: 6$, $150 \mathrm{kPa}$ ) were used in the headspace. The gas-to-liquid ratio was $1: 2(\mathrm{v} / \mathrm{v})$. The inoculated culture medium was incubated at room temperature (approximately $25^{\circ} \mathrm{C}$ ) with continuous shaking in the laboratory. The enrichment culture contained non-motile, small, spherical cells, and these were purified by the dilution-to-extinction technique of Baross (1995). The culture in the tube showing growth at the highest dilution was designated strain $42 \mathrm{BKT}^{\mathrm{T}}$. Purity was confirmed routinely by microscopic examination and by repeated partial sequencing of the $16 \mathrm{~S}$ rRNA gene using several PCR primers. Strain $42 \mathrm{BKT}^{\mathrm{T}}$ was routinely cultivated with $\mathrm{MJ}-\mathrm{N}$ basal medium containing $0 \cdot 2 \%(\mathrm{w} / \mathrm{v}) \mathrm{NaNO}_{3}$ supplemented in $\mathrm{MJ}$ basal medium instead of oxygen as a sole electron acceptor $(\mathrm{pH} 6 \cdot 8)$. The gas mixture in the headspace of the MJ-N basal medium was $\mathrm{N}_{2} / \mathrm{CO}_{2}(80: 20,150 \mathrm{kPa})$.

\section{Morphology}

Cells were routinely observed under a phase-contrast Olympus BX51 microscope with the Olympus Camedia C3030 digital camera system. Cells grown in MJ-N basal medium at $30{ }^{\circ} \mathrm{C}$ in the mid-exponential phase of growth were negatively stained with $2 \%(\mathrm{w} / \mathrm{v})$ uranyl acetate and observed under a JEOL JEM-1210 transmission electron microscope at an accelerating voltage of $120 \mathrm{kV}$ (Zillig et al., $1990)$. Cells of strain $42 \mathrm{BKT}^{\mathrm{T}}$ were Gram-negative, nonmotile, coccoid to short rods resembling eggs, about $0 \cdot 5-$ $1 \cdot 2 \mu \mathrm{m}$ long and $0 \cdot 4-0 \cdot 8 \mu \mathrm{m}$ wide (Fig. 1a). Thin sections were prepared after fixation in $4.0 \%(\mathrm{w} / \mathrm{v})$ paraformaldehyde overnight at room temperature, and then post-fixed with $1 \%(\mathrm{v} / \mathrm{v}) \mathrm{OsO}_{4}$. Specimens were embedded in Spurr's resin overnight and then cut using an ultramicrotome. Thin sections were stained in $2 \%(\mathrm{w} / \mathrm{v})$ uranyl acetate and observed with a JEOL JEM-1210 electron microscope. Thin sections revealed that the isolate had cell wall typical of Gram-negative bacteria (Fig. 1b). The formation of spores or flagella was never observed. The size and morphology of the cell were constant under aerobic and anaerobic conditions.

\section{Growth characteristics}

Growth of the isolate was monitored by direct counting of DAPI-stained cells under the epifluorescence microscope 


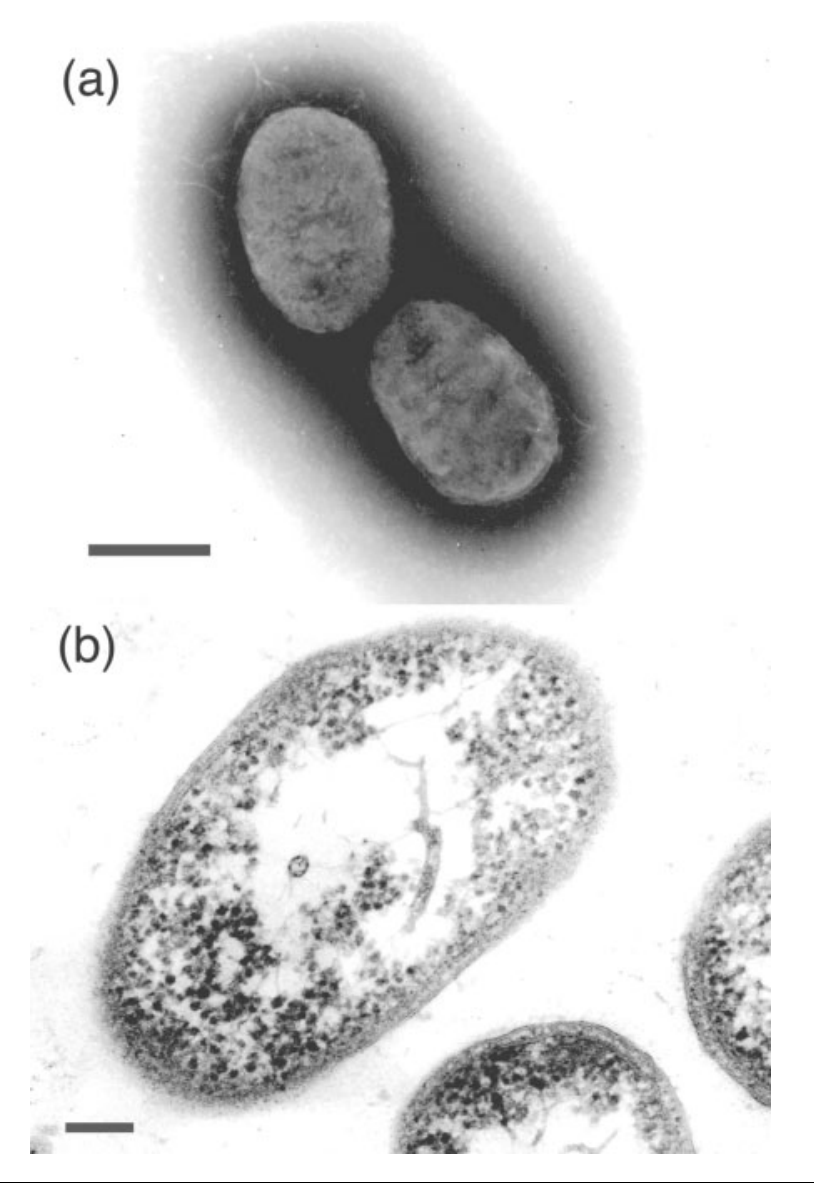

Fig. 1. Electron micrographs of a negatively stained cell (a) and a thin section (b) of strain $42 \mathrm{BKT}^{\mathrm{T}}$. Bars, $0.5 \mu \mathrm{m}$ (a) and $0 \cdot 1 \mu \mathrm{m}$ (b).

(Porter \& Feig, 1980). All experiments described below were conducted in duplicate. To determine the optimum growth temperature, cells were grown in $\mathrm{MJ}-\mathrm{N}$ basal medium with continuous shaking as described above. Strain $42 \mathrm{BKT}^{\mathrm{T}}$ grew at a temperature range of $10-40{ }^{\circ} \mathrm{C}$, with optimal growth at $28-30^{\circ} \mathrm{C}$ (Table 1). No growth was observed below 8 or above $42^{\circ} \mathrm{C}$. To determine the effect of $\mathrm{pH}$ on growth, the $\mathrm{pH}$ of MJ-N basal medium was adjusted to various levels with $10 \mathrm{mM}$ acetate/acetic acid

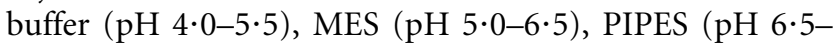
$7 \cdot 0$ ), HEPES ( $\mathrm{pH} 7 \cdot 0-8 \cdot 0$ ) and $10-30 \mathrm{mM}$ Tris $(\mathrm{pH} 8 \cdot 0$ and above). The $\mathrm{pH}$ was checked after adding $\mathrm{NaHCO}_{3}$ and $\mathrm{CO}_{2}$ gas and was readjusted with $\mathrm{H}_{2} \mathrm{SO}_{4}$ or $\mathrm{NaOH}$ at room temperature if necessary. Growth occurred at $\mathrm{pH} 5 \cdot 0-9 \cdot 0$, with optimal growth at around $6 \cdot 5-7 \cdot 0$. Very weak growth was observed at $\mathrm{pH} 9 \cdot 0$ and $5 \cdot 0$ with continuous $\mathrm{pH}$ control during cell growth. No growth was observed at $\mathrm{pH} 4.5$ or 9.5 . The isolate required sea salts for growth. Strain $42 \mathrm{BKT}^{\mathrm{T}}$ grew over the salinity range of 5-60 $\mathrm{g} \mathrm{l}^{-1}$, with optimum growth at $40 \mathrm{~g}$ total salt $\mathrm{l}^{-1}$ at $28^{\circ} \mathrm{C}$, pH $6 \cdot 7$. Oxygen sensitivity was examined using
MJ basal medium without nitrate with a varying oxygen concentration in the headspace gas during incubation at $28{ }^{\circ} \mathrm{C}, \mathrm{pH} 6.7$ and $4.0 \%(\mathrm{w} / \mathrm{v})$ sea salt concentration. Growth of the isolate was observed at $1-7 \cdot 5 \%(\mathrm{v} / \mathrm{v})$ oxygen; the optimum concentration was $5 \cdot 0 \%(\mathrm{v} / \mathrm{v})$. No growth was observed without oxygen or with over $12 \%(\mathrm{v} / \mathrm{v})$ in headspace gas. No growth was observed with air in the headspace. In optimum growth conditions in MJ basal medium at $28{ }^{\circ} \mathrm{C}$, pH $6 \cdot 7,4 \cdot 0 \%(\mathrm{w} / \mathrm{v})$ sea salt and $5 \%(\mathrm{v} / \mathrm{v})$ oxygen, the final density of the cells was approximately $6.8 \times 10^{8}$ cells $\mathrm{ml}^{-1}$ in culture medium, with a doubling time of approximately $1.5 \mathrm{~h}$. When the isolate was cultured in MJ-N basal medium under anoxic conditions, the final cell density was $3 \cdot 1 \times 10^{8}$ cells ml $^{-1}$. Cell growth in MJ-N basal medium was stimulated by adding sodium sulfide. Cell density in MJ-N basal medium containing 0.05\% $\mathrm{Na}_{2} \mathrm{~S} .9 \mathrm{H}_{2} \mathrm{O}$ was approximately twofold higher than without $\mathrm{Na}_{2} \mathrm{~S} .9 \mathrm{H}_{2} \mathrm{O}$. However, the isolate did not utilize sulfide as an electron donor as described below. Graphs showing the effects of temperature, $\mathrm{pH}$, sea salts and headspace oxygen concentration on growth are available as supplementary material in IJSEM Online.

\section{Metabolic characteristics}

Strain $42 \mathrm{BKT}^{\mathrm{T}}$ is a strict chemolithoautotrophic sulfuroxidizing bacterium capable of growth with elemental sulfur $\left(S^{0}\right)$ or thiosulfate as an electron donor (Table 1 ). To determine the end product of elemental sulfur or thiosulfate oxidation, the isolate was cultivated in medium supplemented with sulfate-free MJ synthetic sea water containing $\mathrm{MgCl}_{2}$ instead of $\mathrm{MgSO}_{4}$ (i.e. containing 7.58 $\mathrm{g} \mathrm{MgCl}_{2} \mathrm{l}^{-1}$ ); the sulfate concentration was monitored by HPLC (Shimadzu) (Inagaki et al., 2003). Results showed that almost all $7 \cdot 5 \mathrm{mM}$ thiosulfate was oxidized to $15 \mathrm{mM}$ sulfate during cell growth, suggesting that sulfate was the end product of sulfur oxidation (Fig. 2). The following substrates added to the medium as potential electron donors did not support growth of the isolate: $0.02 \%(\mathrm{w} / \mathrm{v})$ $\mathrm{Na}_{2} \mathrm{~S} .9 \mathrm{H}_{2} \mathrm{O}$ or cysteine hydrochloride, 5 or $0.5 \mathrm{mM}$ each of $\mathrm{Na}_{2} \mathrm{SO}_{3}, \mathrm{Na}_{2} \mathrm{~S}_{2} \mathrm{O}_{3}, \mathrm{Na}_{2} \mathrm{~S}_{2} \mathrm{O}_{4}, \mathrm{Na}_{2} \mathrm{~S}_{2} \mathrm{O}_{5}, \mathrm{Na}_{2} \mathrm{~S}_{2} \mathrm{O}_{7}$ or $\mathrm{Na}_{2} \mathrm{~S}_{2} \mathrm{O}_{8}$ (the last three compounds were obtained from Wako Purechemical; purity $64-67 \cdot 4,>98$ and $>97 \%$, respectively), $0 \cdot 1$ or $0 \cdot 01 \%(\mathrm{w} / \mathrm{v})$ each of yeast extract or peptone, 5 or $0.5 \mathrm{mM}$ each of glucose, maltose, sucrose, methanol, ethanol, 2-propanol, formate, acetate, lactate, tartaric acid, fumarate, malate, pyruvate, ascorbic acid, succinate, nitrilotriacetic acid (NTA) or thioglycolic acid, $0.01 \%$ methionine or $5 \mathrm{mM}$ sodium chlorate. The ability to use molecular hydrogen was examined by using a gas mixture of $\mathrm{H}_{2}$ and $\mathrm{CO}_{2}(80: 20,200 \mathrm{kPa})$ in the headspace with $\mathrm{MJ}-\mathrm{N}$ basal medium, but no growth was observed. The isolate can use oxygen ( $<7.5 \%$ in the headspace) and nitrate as an electron acceptor (Table 1, supplementary material). Other potential electron acceptors, such as $5 \mathrm{mM}$ and $0.5 \mathrm{mM}$ each of $\mathrm{Na}_{2} \mathrm{SO}_{4}, \mathrm{Na}_{2} \mathrm{SO}_{3}$ and $\mathrm{NaNO}_{2}$, fumarate, $1 \%(\mathrm{v} / \mathrm{v})$ ferrihydrite and manganese (IV), were unable to support growth. Production of ammonium and $\mathrm{N}_{2} \mathrm{O}$ by nitrate reduction 


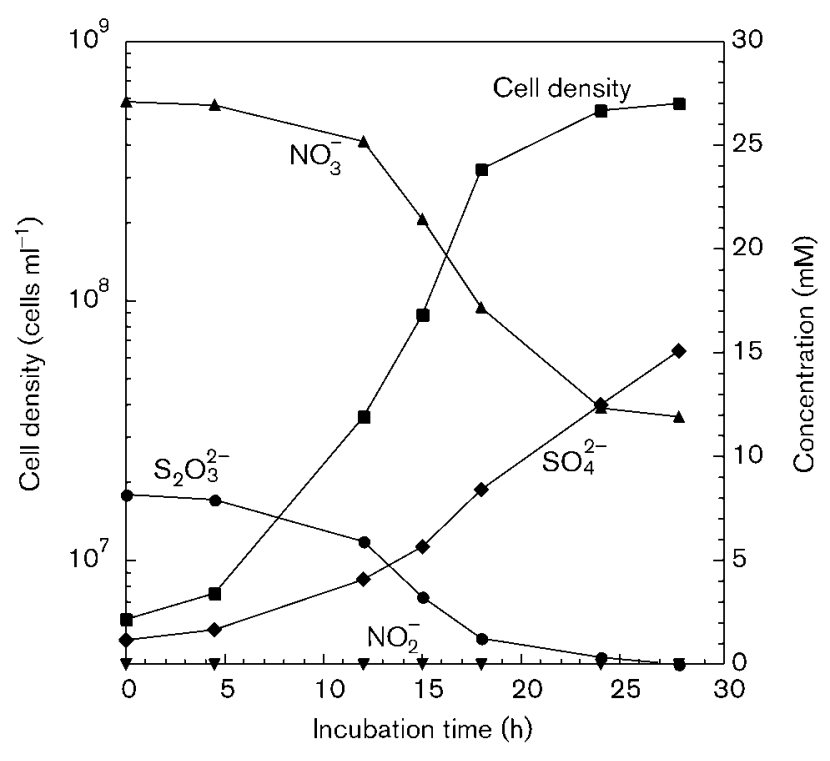

Fig. 2. Changes in thiosulfate $(\boldsymbol{O})$, sulfate $(\boldsymbol{\nabla})$, nitrate $(\boldsymbol{\Delta})$ and nitrite $(\boldsymbol{\nabla})$ concentrations during growth of strain $42 \mathrm{BKT}^{\top} . \mathbf{\square}$, Cell density.

was monitored by Nessler's solution (Wako) and Micro GC CP2002 gas chromatography (GL Sciences), respectively. Ammonium and $\mathrm{N}_{2} \mathrm{O}$ were not detected during cell growth. Cell growth was inhibited by the presence of $0.2 \mathrm{mM}$ $\mathrm{NaNO}_{2}$ in MJ basal medium. No production of nitrite was observed by HPLC (Fig. 2).

In $\mathrm{MJ}$ basal medium, strain $42 \mathrm{BKT}^{\mathrm{T}}$ was able to use only $\mathrm{NH}_{4} \mathrm{Cl}$ as sole nitrogen source. When 5 or $0 \cdot 1 \mathrm{mM} \mathrm{NaNO}_{2}$ or $\mathrm{NaNO}_{3}$ was added as a potential nitrogen source instead of $\mathrm{NH}_{4} \mathrm{Cl}$ and the gas phase was filled with $\mathrm{H}_{2} / \mathrm{CO}_{2} / \mathrm{O}_{2}$ $(77 \cdot 5: 17 \cdot 5: 5,150 \mathrm{kPa})$, cell growth was not observed, although the strain was able to use $\mathrm{NaNO}_{3}$ as an electron acceptor. Utilization of nitrogen gas was examined using a gas mixture of $\mathrm{N}_{2} / \mathrm{CO}_{2} / \mathrm{O}_{2}(77 \cdot 5: 17 \cdot 5: 5,150 \mathrm{kPa})$ and $\mathrm{NH}_{4} \mathrm{Cl}$-free $\mathrm{MJ}$ basal medium, but no growth was observed.

\section{Fatty acid and DNA base compositions}

The cellular fatty acid composition of the isolate and DNA $\mathrm{G}+\mathrm{C}$ content of strain $42 \mathrm{BKT}^{\mathrm{T}}$ were analysed by GC/MS (Komagata \& Suzuki, 1987) and HPLC (Tamaoka \& Komagata, 1984), respectively. Cells grown in MJ-N basal medium at $28{ }^{\circ} \mathrm{C}$ in the late exponential growth phase were used for these analyses. The major cellular fatty acids were $\mathrm{C}_{16: 1 \text { cis }}(53 \cdot 7 \%), \mathrm{C}_{16: 0}(31 \cdot 3 \%)$ and $\mathrm{C}_{18: 0}(15 \cdot 0 \%)$. $\mathrm{C}_{14: 0}$ was not detected in strain $42 \mathrm{BKT}^{\mathrm{T}}$, although the fatty acids of Sulfurimonas autotrophica OK $10^{\mathrm{T}}$ contained $8 \cdot 4 \%$ $\mathrm{C}_{14: 0}$ (Inagaki et al., 2003). The $\mathrm{G}+\mathrm{C}$ content of the genomic DNA was $48.0 \mathrm{~mol} \%$, a value higher than that of other $\varepsilon$-proteobacteria isolated from hydrothermal systems (Table 1).

\section{Phylogenetic position and ecological significance}

The PCR-amplified 16S rRNA gene (1406 bp) of strain $42 \mathrm{BKT}^{\mathrm{T}}$ was sequenced on both strands with a model 3100 automatic capillary sequencer (Perkin Elmer/Applied Biosystems). The $16 \mathrm{~S}$ rRNA gene sequence was subjected to sequence similarity analysis against the nucleotide sequence databases of GenBank, EMBL and DDBJ using the gapped-BLAST and FASTA search algorithms. Similarity analysis indicated that the $16 \mathrm{~S}$ rRNA gene sequence of strain $42 \mathrm{BKT}^{\mathrm{T}}$ was closely related to an uncultivated environmental sequence of a2b004 (98.5\%) detected from hydrothermal sediments in the Guaymas Basin (Teske et al., 2002) and NKB9 (96.2\%) from deep-sea cold seep sediments in the Nankai Trough (Li et al., 1999). The most closely related sequence of a previously cultivated and identified strain was Wolinella succinogenes ATCC $29543^{\mathrm{T}}(82 \cdot 2 \%)$. Phylogenetic analysis revealed that the isolate was located within the uncultivated $\varepsilon$-proteobacterial group F (Corre et al., 2001) (Table 1, Fig. 3). Group F contains large numbers of environmental sequences obtained from deep-sea hydrothermal systems (Reysenbach et al., 2000; Teske et al., 2002) and cold seep environments (Li et al., 1999; Inagaki et al., 2002) (Fig. 3). Indeed, strain $42 \mathrm{BKT}^{\mathrm{T}}$ was isolated from low-temperature sediments associated with gas-bubbling in the mid-Okinawa Trough back-arc hydrothermal system. In addition, group $\mathrm{F}$ contains the episymbionts of both the alvinellid polychetes (bootstrap value $61 \%$ ) and shrimp ectosymbionts (bootstrap value $99 \%$ ) (Fig. 3). Physiological characteristics of the isolate were completely different from those of previously cultivated thermophilic $\varepsilon$-proteobacteria from deepsea hydrothermal systems, such as the genera Caminibacter (Alain et al., 2002), Nautilia (Miroshnichenko et al., 2002) and Hydrogenimonas (Takai et al., 2004). The growth temperature ranges and the ability to utilize hydrogen or oxygen of these genera might fit with the geochemical settings of indigenous habitats. We have previously reported that members of $\varepsilon$-proteobacterial group $\mathrm{F}$ coexist with sulfate reducers within the $\delta$-Proteobacteria in deep-sea cold seep environments (Inagaki et al., 2002). Mesophilic sulfur-oxidizing bacteria phylogenetically related to isolate $42 \mathrm{BKT}^{\mathrm{T}}$ might contribute to sulfur (re)cycling in global deep-sea environments.

\section{Description of Sulfurovum gen. nov.}

Sulfurovum [Sul.fu.ro'vum. L. neut. n. sulfur sulfur; L. neut. n. ovum egg; N.L. neut. n. Sulfurovum sulfur (-oxidizing) egg].

Cells are Gram-negative, non-motile, coccoid to short rods. Mesophilic facultative anaerobes that require sea salts for growth. Growth occurs chemolithoautotrophically with elemental sulfur or thiosulfate as an electron donor and with oxygen and nitrate as an electron acceptor using $\mathrm{CO}_{2}$ as the carbon source. 16S rRNA gene sequence analysis 


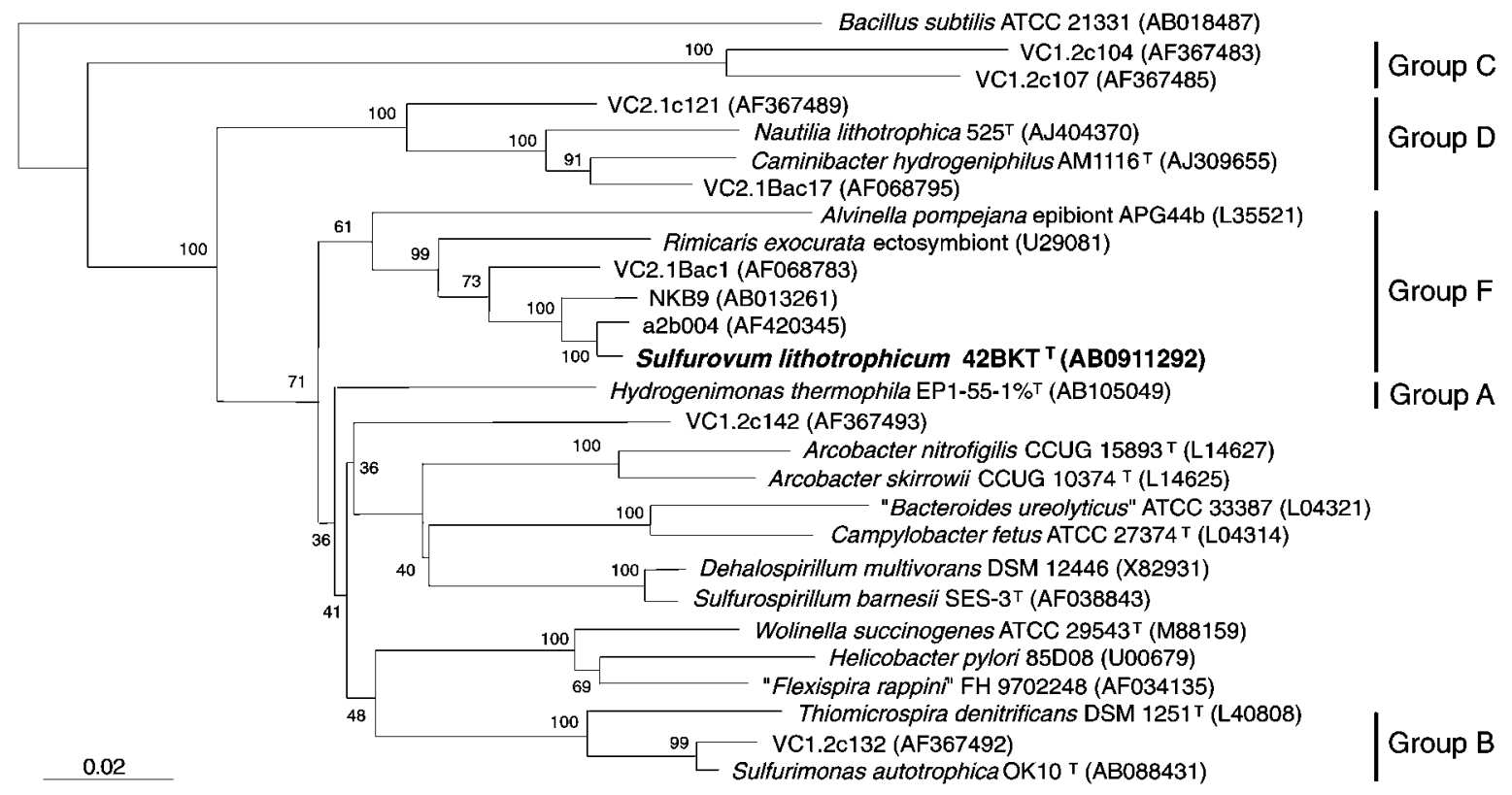

Fig. 3. Phylogenetic position of the novel isolate based on $16 \mathrm{~S}$ rDNA sequences, including representative members and uncultivated environmental rDNA sequences within the $\varepsilon$-Proteobacteria. The tree was constructed by the neighbour-joining method in the DDBJ CLUSTAL $x$ system (Thompson et al., 1997) using 1170 homologous positions that could be aligned unambiguously in all examined sequences. Least-squares distance matrix based on evolutionary distances was performed using the correction of Kimura (1980). Accession numbers in EMBL/GenBank/DDBJ databases are shown in parentheses. Numbers at nodes represent bootstrap values (100 replicates). Classification of $16 \mathrm{~S}$ rDNA lineages is according to Corre et al. (2001). The sequence of Bacillus subtilis was used as outgroup. Bar, 2 substitutions per 100 nucleotides.

locates the genus within the $\varepsilon$-Proteobacteria. The type species is Sulfurovum lithotrophicum.

\section{Description of Sulfurovum lithotrophicum sp. nov.}

Sulfurovum lithotrophicum (li.tho.tro' phi.cum. Gr. masc. n. lithos stone; Gr. adj. trophikos nursing, tending or feeding; N.L. neut. adj. lithotrophicum feeding on inorganic substrates).

Displays the following properties in addition to those given in the genus description. Cells are $0 \cdot 5-1 \cdot 2 \mu \mathrm{m}$ long and $0 \cdot 4-0 \cdot 8 \mu \mathrm{m}$ wide. The temperature range for growth is $10-40{ }^{\circ} \mathrm{C}$ (optimum $28-30^{\circ} \mathrm{C}$ ). The $\mathrm{pH}$ range for growth is $4 \cdot 5-9 \cdot 0$ (optimum $6 \cdot 5-7 \cdot 0$ ). Sea salts are required for growth; the concentration range is $10-60 \mathrm{~g} \mathrm{l}^{-1}$ (optimum $40 \mathrm{~g}^{-1}$ ). Ammonium is required as a nitrogen source for growth. Cells require nitrate or oxygen at $<7 \cdot 5 \%$ in the headspace gas (optimum $5 \%, 150 \mathrm{kPa}$ ) as an electron acceptor. Organic acids, alcohols, sugars and hydrogen do not support growth. The major cellular fatty acids are $\mathrm{C}_{16: 1 \text { cis }}(53 \cdot 7 \%), \mathrm{C}_{16: 0}(31 \cdot 3 \%)$ and $\mathrm{C}_{18: 0}(15 \cdot 0 \%)$. The $\mathrm{G}+\mathrm{C}$ content of the DNA is $48 \cdot 04 \pm 0 \cdot 5 \mathrm{~mol} \%$ (HPLC). The GenBank/EMBL/DDBJ accession number for the $16 \mathrm{~S}$ rRNA gene sequence of the type strain is AB091292.

The type strain, $42 \mathrm{BKT}^{\mathrm{T}} \quad\left(=\mathrm{ATCC}\right.$ BAA $-797^{\mathrm{T}}=\mathrm{JCM}$
$12117^{\mathrm{T}}$ ), was isolated from deep-sea hydrothermal sediments at the Iheya North hydrothermal field in the midOkinawa Trough, Japan.

\section{Acknowledgements}

We would like to thank Dr K. Uematsu for assistance in preparing electron micrographs. We are very grateful to the NT02-06 onboard scientific party for useful discussions, and to the R/V Natsushima and Shinkai 2000 operation teams for helping us to collect sediment samples from the deep-sea hydrothermal vent field.

\section{References}

Alain, K., Querellou, J., Lesongeur, F., Pignet, P., Crassous, P., Raguénès, G., Cueff, V. \& Cambon-Bonavita, M.-A. (2002). Caminibacter hydrogeniphilus gen. nov., sp. nov., a novel thermophilic, hydrogen-oxidizing bacterium isolated from an East Pacific Rise hydrothermal vent. Int J Syst Evol Microbiol 52, 1317-1323.

Balch, W. E., Fox, G. E., Magrum, L. J., Woese, C. R. \& Wolfe, R. S. (1979). Methanogens: reevaluation of a unique biological group. Microbiol Rev 43, 260-296.

Baross, J. A. (1995). Isolation, growth and maintenance of hyperthermophiles. In Archaea: a Laboratory Manual. Thermophiles, pp. 15-23. Edited by F. T. Robb \& A. R. Place. Cold Springer Harbor, NY: Cold Spring Harbor Laboratory.

Campbell, B. J., Jeanthon, C., Kostka, J. E., Luther, G. W., III \& Cary, S. C. (2001). Growth and phylogenetic properties of novel bacteria belonging to the epsilon subdivision of the Proteobacteria enriched 
from Alvinella pompejana and deep-sea hydrothermal vents. Appl Environ Microbiol 67, 4566-4572.

Corre, E., Reysenbach, A.-L. \& Prieur, D. (2001). Epsilonproteobacterial diversity from a deep-sea hydrothermal vent on the Mid-Atlantic Ridge. FEMS Microbiol Lett 205, 329-335.

Inagaki, F., Sakihama, Y., Inoue, A., Kato, C. \& Horikoshi, K. (2002). Molecular phylogenetic analyses of reverse-transcribed bacterial rRNA obtained from deep-sea cold seep sediments. Environ Microbiol 4, 277-286.

Inagaki, F., Takai, K., Nealson, K. H. \& Horikoshi, K. (2003). Sulfurimonas autotrophica gen. nov., sp. nov., a novel sulfur-oxidizing epsilon-proteobacterium isolated from hydrothermal sediments in the mid-Okinawa Trough. Int J Syst Evol Microbiol 53, 1801-1805.

Kimura, M. (1980). A simple method for estimating evolutionary rates of base substitutions through comparative studies of nucleotide sequences. J Mol Evol 16, 111-120.

Komagata, K. \& Suzuki, K. (1987). Lipid and cell-wall analysis in bacterial systematics. Methods Microbiol 19, 161-207.

Li, L., Guezennec, J., Nichols, P., Henry, P., Yanagibayashi, M. \& Kato, C. (1999). Microbial diversity in Nankai Trough sediments at a depth of 3,843m. J Oceanogr 55, 635-642.

Longnecker, K. \& Reysenbach, A.-L. (2001). Expansion of the geographic distribution of a novel lineage of epsilon-Proteobacteria to a hydrothermal vent site on the Southern East Pacific Rise. FEMS Microbiol Lett 35, 287-293.

Miroshnichenko, M. L., Kostrikina, N. A., L'Haridon, S., Jeanthon, C., Hippe, H., Stackebrandt, E. \& Bonch-Osmolovskaya, E. A. (2002). Nautilia lithotrophica gen. nov., sp. nov., a thermophilic sulfurreducing $\varepsilon$-proteobacterium isolated from a deep-sea hydrothermal vent. Int J Syst Evol Microbiol 52, 1299-1304.

Moyer, C. L., Dobbs, F. C. \& Karl, D. M. (1995). Phylogenetic diversity of the bacterial community from a microbial mat at an active, hydrothermal vent system, Loihi Seamount, Hawaii. Appl Environ Microbiol 61, 1555-1562.
Polz, M. F. \& Cavanaugh, C. M. (1995). Dominance of one bacterial phylotype at a Mid-Atlantic Ridge hydrothermal vent site. Proc Natl Acad Sci U S A 92, 7232-7236.

Porter, K. G. \& Feig, Y. S. (1980). The use of DAPI for identifying and counting microflora. Limnol Oceanogr 25, 943-948.

Reysenbach, A. L., Longnecker, K. \& Kirshtein, J. (2000). Novel bacterial and archaeal lineages from an in situ growth chamber deployed at a Mid-Atlantic Ridge hydrothermal vent. Appl Environ Microbiol 66, 3798-3806.

Takai, K., Inagaki, F., Nakagawa, S., Hirayama, H., Nunoura, T., Sako, Y., Nealson, K. H. \& Horikoshi, K. (2003). Isolation and phylogenetic diversity of members of previously uncultivated epsilon-Proteobacteria in deep-sea hydrothermal fields. FEMS Microbiol Lett 218, 167-174.

Takai, K., Nealson, K. H. \& Horikoshi, K. (2004). Hydrogenimonas thermophila gen. nov., sp. nov., a novel thermophilic, hydrogenoxidizing chemolithoautotroph within the $\varepsilon$-Proteobacteria isolated from a black smoker in a Central Indian Ridge hydrothermal field. Int J Syst Evol Microbiol 54, 25-32.

Tamaoka, J. \& Komagata, K. (1984). Determination of DNA base composition by reversed-phase high-performance liquid chromatography. FEMS Microbiol Lett 25, 125-128.

Teske, A., Hinrichs, K. U., Edgcomb, V., de Vera Gomez, A., Kysela, D., Sylva, S. P., Sogin, M. L. \& Jannasch, H. W. (2002). Microbial diversity of hydrothermal sediments in the Guaymas Basin: evidence for anaerobic methanotrophic communities. Appl Environ Microbiol 68, 1994-2007.

Thompson, J. D., Gibson, T. J., Plewniak, F., Jeanmougin, F. \& Higgins, D. G. (1997). The CLUSTAL_X Windows interface: flexible strategies for multiple sequence alignment aided by quality analysis tools. Nucleic Acids Res 25, 4876-4882.

Zillig, W., Holz, I., Janekovic, D. \& 7 other authors (1990). Hyperthermus butylicus, a hyperthermophilic sulfur-reducing archaebacterium that ferments peptides. J Bacteriol 172, 3959-3965. 